\title{
On the Simplest Reading of Bartol's Alamut
}

\author{
Tahereh AHMADIPOUR*
}

\begin{abstract}
Bartol's Alamut as a valuable Slovenian literary work has been exposed to several interpretations for more than 70 years. The simplest or maybe the most credulous reading of this book is the one that considers it as a history book. This reading deems that the novel literally narrates the political and social events of Iran in the 11th century, the time that the Ismailis with Hasan Sabbah as the leader ruled over Alamut Castle. In this article the novel's most important interpretations have been provided by discussing the deliberate critical essays through content analysis and historical criticism of the happenings. Then by using some important historical documents and relevant evidence, some events and persons of that time have been detected. The main aim of the article is to show that while Bartol incorporated a vast knowledge of the history of the Middle East as the core part of his novel, he also regarded his own nation and the miserable events of his own country. As a matter of fact he sent a harsh message through creating his own Hasan Sabbah, without any concern for the history.
\end{abstract}

Keywords: Bartol's Alamut, Hasan Sabbah, historical Criticism, Slovene literature

\section{Izvleček}

Bartolov Alamut je pomembno slovensko delo, ki je že skoraj 70 let tema številnih interpretacij. Najpreprosteje, celo lahkoverno je to delo brati kot zgodovinsko knjigo. Takšno branje predpostavlja, da roman $\mathrm{v}$ resnici pripoveduje o političnih in družbenih dogodkih v Iranu 11. stoletja, v času, ko sta Esmail in Hasan Sabah vladala Alamutovemu gradu. $\mathrm{V}$ tem članku so poudarjene najpomembnejše interpretacije romana $z$ diskusijo dveh premišljenih kritičnih esejev skozi analizo vsebine in zgodovinsko kritiko dogajanja. Z uporabo nekaterih pomembnih zgodovinskih dokumentov in z relevantnimi dokazi so bili odkriti nekateri dogodki in osebe tistega časa. Glavni cilj članka je pokazati, da je Bartol dobro poznal zgodovino Bližnjega vzhoda, kar je bila osnova za osrednji del tega romana, prav tako pa je upošteval svoj narod in nesrečne dogodke v lastni državi. Pravzaprav je prek svojega Hasana Sabaha podal kruto sporočilo, ne ozirajoč se na zgodovino.

Ključne besede: Bartolov Alamut, Hasan Sabah, zgodovinska kritika, slovenska literatura

Tahereh AHMADIPOUR, Associate professor in sociolinguistics.

Department of Linguistics and Translation Studies,

Vali-E-Asr University, Rafsanjan, Iran.

Tahereh.ahmadipour12[at]gmail.com

ahmadipour[at]vru.ac.ir

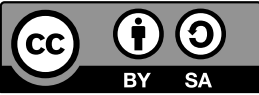




\section{Introduction}

When I started reading Alamut, I did not imagine how fascinating and impressive this literary masterpiece could be. As a person from the Middle East I felt really at home with the setting, so familiar to me, so timeless, so appealing and easy to follow that it could draw me up to the end. The reader can be certain that the author has lived at least for some time in that colorful setting. The novel shares a wealth of knowledge about the Middle East from various points of view including culture, history, human psychology, religion, politics, and philosophy. This novel encouraged me to start reading and researching about some real facts about Alamut Castle and Hasan Sabbah, as well as some commentaries on the novel. Among the many materials written on Bartol's Alamut over the years, two reviews touched me the most. One was by Michael Biggins (2005), the other is a review essay written on Biggins' mentioned article by Miran Hladnik (2005). Both of the essays are still fresh with some sound and deliberated ideas, capable of being discussed and used to present my own comments. The two reviewers provided and argued the different interpretations of Bartol's novel. I am going to talk over the simplest interpretations of the novel referred by Biggins, namely the possibility of the relationship between the novel and history. I try to provide some answers for the following questions: How much is the novel, Alamut, a reflection of some historical happenings? To what extent is the main character of the novel, Hasan Sabbah, similar to the Hasan Sabbah in real world in 11th century in Alamut Castle? How Bartole used history at the service of his own purpose?

\section{A Review on the Two Related Essays}

Biggins examines the social and political situation of Slovenia in and around the time Bartol's writing Alamut in 1938. He mentions that when Bartol was writing the novel, to the west, "Italy's fascists regularly hounded the large ethnic Slovenian minority of the Adriatic seacoast town of Trieste" (Biggins 2005, 428), i.e. Bartol's home town. They decided to extend their territory into Slovenia and other countries. At the same time, as he worked on an early draft, barely thirty miles to the north Austeria was forcibly annexed to Nazi Germany. A little bit farther to the east in the Soviet Union, with Stalin as its leader, quite a lot of people were murdered. By depicting the picture of such circumstances, Biggins tends to prove that Bartol's writing of Alamut was "an escape from the mass political movements, charismatic leaders, and manipulative ideologies" (ibid., 428-31). On the other hand Hladnik cannot tolerate this comment and doesn't believe in the notion that writing Alamut in such a situation can be regarded as "a profound meditation", 
on the disastrous happenings of the time. Hladnik gives a harsh critical attitude towards considering Bartol as a "cosmopolitan" writer and not a "nationalistic" one. He cannot accept Bartol is being characterized as "a mistake in the Slovenian genetic code", and Alamut as an adventurous novel or even a mere literary masterpiece.

Biggins classified different approaches to interpret the Alamut. The first is regarding it "as a broadly historical if highly fictionalized account of eleventh century Iran under Seljuk rule" (Biggins 2005, 430). He deems the novel deserves to be appreciated because of "scrupulously researched historical background" and also the "general absence of historical anachronisms". He enumerates many of the novel's features that show Bartol to have been quite knowledgeable about the people, time, place, and all the happenings of that settings "for over a millennium". The second interpretation of the novel in Biggins' classifications is to view it as an allegory of totalitarian regimes between the two world wars in early twentieth century in Europe. Bartol depicts Hasan Sabbah, a dictator leader as a personality so similar to Mussolini, Hitler and Stalin. Biggins thinks that there are similarities between the happenings, personalities, and hierarchical organizations of the Ismailis that Bartol used in the novel and the ones in real life at Bartol's time. Hladnik also finds this possible for such "allusions to Nazi political figures and events of that time". The third interpretation that Biggins denies to accept, but which Hladnik embraces is the notion of viewing Bartol as a "nationalistic" writer. Based on this reading, Alamut is "a roman-e-clef", meaning a novel with a key, about a real life, which shows a good response to totalitarianism. It seems that he dreams asking "Why not have a leader such as Hasan in all the disasters that came to the Slovenian nation from the foreign dictators of the era". If so, what does Hasan mean for Bartol's community, a savior of the nation or a dictator? Then both Biggins and Hladnik touch on the real-life of Bartol's best friend Zorko, the head of a Slovenian terrorist group who was captured and accused by Italians in 1930 showing Bartol's note in his diary: "Zorko, I will avenge you". Hladnik disputes Biggins, deciding rather in favor of this interpretation. Hladnik claims that his interpretation is based on some other subtle commentaries such as Lino Legiša's, who are completely familiar with Bartol's circumstances while creating the novel. Then he discusses different readings put forward by Biggins. He analyses that if there is a lot devotion in the novel to "Hasan's demonic rationalism and nihilism", the "theme of evil" has always been more interesting than anything else even in "positive moralistic teaching". He uses the lines of Bartol's thought through his attitudes in Al Araf, Bartol's other book written before Alamut, when he says, "he who wants to become master of his own fate should follow the dogs". Hladnik aims to say that this is Bartol's message to the Slovenian people begun in 
Al Araf and completed in Alamut. The fourth interpretation proposed by Biggins, which he thinks be new, says that Alamut can reflect the conflict between America (which behaves cruelly) and the Islamic world, and then America receives terroristic actions as revenge. This kind of struggle between "a massive, lumbering empire" and "a small group of close woven network of self-sacrificing agents" remind us that this is a fundamental conflict that originated more than one thousand years ago. Biggins defends the position of the small group by criticizing the other side as an "arrogant, self-satisfied occupying power whose chief goal is finding ways of extracting new profits from its possessions". Biggins still does not think that this interpretation can be so perceptive however one may find some similarity between Bartol's 11th century and the recent political events around the world.

Obviously Biggins does not consider any of the interpretations as a favorite, because he believes each has been folded with ideologies. He turns to the view that Alamut, as a work of literature with the specific task, does not "conveying facts in a linear way". On the other hand Hladnik deems literature as "a laboratory" for testing the solution of social problems in a fictional way. He tries to send the message that Alamut instructs solutions for an endangered community, but of course a very dangerous solution that at this time Hladnik does not recommend it as the best to remove the human beings' dilemma.

\section{Purpose for the Historical Approach}

My contribution to these reviews is of another sort, a sort of explanation about some real persons and happenings in Alamut castle in Iran in the 11th century especially on the main character Hasan Sabbah. As Hladnik argued that "for a long time already the artistic fame of the novel Alamut has not depended on the novel itself, but on numerous critical, essayistic, and literary historical explanations", then my view of the novel may possibly play a small role in discoveries of Bartol's thoughts as reflected in the novel. Actually Biggins and Hladnik have rejected the historical interpretation to be the best reading of the novel and I am not in favor of it as well. I intend to add some information for Alamut's readers to let them know how Bartol imaginatively and skillfully blends fiction and reality for his own intention.

Some time before I came across an interview with the producer the Assassin's Creed Games, developed by Ubisoft Montreal, which has won a number of awards. She asserted that the series took inspiration from the novel Alamut by Bartol. She has said, "It is not just a game, but a crusade to revolutionize a genre" (CVG UK 2006). In some of the nontechnical, jotted-down reviews of Alamut, the novel itself has been regarded as a history book showing Islam, Iran, and 
Iranian culture. Ordinary readers of Alamut also mostly put their attitudes "on its simplest interpretation”. Some writers also succeeded in making Hasan Sabah and his followers and their beliefs perhaps the symbol of Iran and Iranian and Islam. All these form some cliché or stereotypes about a nation and as we know Bartol through his works we can be certain that Bartol did not mean it. Bartol is an artist who does not want his "beloved" book to become the inspiration for some attitudes other than his. Here he is similar to Moulana Jalāl ad-Dīn Muhammad Rūmī, when in the first poem of Mathnavi he says (Whinfield 1898):

Each interprets my notes in harmony with his own feelings, But not one fathoms the secrets of my heart

\section{A Review on Some of the Real Documents from the Real Alamut in Iran}

As a matter of, fact the story of Hasan Sabbah and the Alamut Castle narrated by Bartol is such a charming one that the reader is tempted to learn how much of the story was real historically. It is so difficult to pull out the facts from all the fallacies during a turbulent period, but based on the different documents the Ismailis were surrounded by a powerful empire against them with some counter-ideologies even for years after their collapse. I do not have any purpose to defend or reject Hasan's personality, ideologies and policies in that period of time because this is not my concern here. As I said I am presenting some of the documentary facts about history to the readers of Alamut who are eager to know in order to differentiate between the people and happenings in the novel and those in reality. One can be sure that Bartol has not created such a masterpiece to be used for purposes other than his. We know that Bartol painted with vast knowledge of the Middle East, despite being from Slovenia. And we know that he was impressed by Marco Polo's travel book, a chapter of which narrates a story about Alamut and its events at Hasan's time. Bartol showed that he could painted an eastern tale rooted in real life, though Biggins expected it to be a masterpiece in European literature and not a mere thesis product and as Hladnik regarded it as a highly nationalistic literary work. I want to say that the portrait of Hasan Sabbah drawn by Bartol is different from the one in 11th century Iran. Bartol deliberately created another Hasan, a gripping personality of his own because of his own goal.

Marco Polo (15 September 1254-8-9 January 1324) was an Italian merchant traveler whose travels are recorded in Livres des merveilles du monde (Book of the Marvels of the World, also known as The Travels of Marco Polo, c. 1300), a book that 
did much to introduce Europeans to Central Asia and China. He narrates the story of Hasan Sabbah based on what he heard from natives of that region. He begins with the other name "The Old Man", which was called in their language "Aloadin". He narrates the story of Hashashin, Da'ian, Fedaiyan, and the artificial paradises and the rest. He narrates that "having first made them drink a certain potion which cast them into a deep sleep, and then causing them to be lifted and carried in. So when they awoke, they found themselves in the Garden (...)." (Polo 1920) Bartol was smart enough to use the story as an attractive part of his own novel, but that was not everything he needed. In the novel there is quite a lot of precise information about the real persons, places and exact times, showing that Bartol had visited reliable historical documents. But the fact is that he was not concerned of all the history because he was not a historian, he applied Marco Polo's story, real history, his own imagination and his noble knowledge of philosophy and personalism along with literature, to make a splendid but fearful creature called Hasan Sabbah. The "laboratory of literature", in Hladnik's words, is the only place such an eminent god-like being could emerge.

There are several different documents and history books about Alamut and Hasan Sabbah in the 11th century because the tradition of historiography in Alamut's time also was prevalent and kings and rulers encouraged these affairs in their courts at least for their own sake. This historiographical tradition commenced with the Sargodhast-e Sayyedna, a work describing the life and the events of the reign of Hasan Sabbah (d. 518 AH/1124 CE) as the first lord of Alamut. The castle was a mountain fortress located in the South Caspian province of Daylam near the Rudbar region in Iran, approximately $100 \mathrm{~km}$ (60 mi) from present-day Tehran, the capital of Iran. The name "Alamut" means "Eagle's Nest". The first part of Sargodhast-e Sayyedna seems to have been autobiographical. After the collapse of Alamut the book has been used by three main historiographers in Ilkhanate (1256-1353) era: This branch of the Mongol dynasty welcomed these three distinguished historians. It is important to know that all these chronicles held at the libraries of Alamut and other Nizari castles in Daylaman and Quhistan are believed to have perished in the Mongol invasions or soon afterwards, during the period of Ilkhanate ruled over Persia. However, these chronicles as well as other Nizari writings and documents were seen before destroying and were used extensively by the three Persian historians of the Ilkhanate period, namely, Juwayni (d. 681 AH/1283 CE) with his main book entitled Ta' rīkh-i jahān-gushā, Rashid-al-Din Fazl-Allah (d. 718 AH/1318 CE) with his history book Jami al-Tawarikh, and Abul-Qasim Kashani (d. ca. 736 AH/1335 CE) with his book Zobdat al-Tawarikh. Indeed, these history books remained the most important primary sources on the Nizari Ismaili state in Persia, and they provided the main sources of reference for later Persian historians, 
like Hamd-Allah Mustawfi (d. after 740 AH/1339 CE) and Hafizi Abru (d. 833 $\mathrm{AH} / 1430 \mathrm{CE}$ ), writing on the subject (Daftary 2007, 176-8).

As the readers of Alamut know, Hasan Sabbah is the most important character of the novel, related to all the other characters and happenings who assigns everything in the plot, his spirit and his thoughts have been deliberately spread all over the novel. That is why I endeavored to put forward some hints of the personality and the doctrine of two Hasans, the head of Alamut Castel and Bartol's main character. I would not like to compare these two because I wonder if they are comparable and whether they belong to the same categories or not. Therefore I simply aim to bring about some existing real documents about Hasan Sabbah, the head of Alamut in 11th century so that and intellectual reader can analyze the relationship between these two Alamuts and two Hasans.

\section{Bartol's Hasan Sabbah}

For Bartol, Hasan Sabbah is a leader with intolerable disgusting dispositions, sometimes immoral and dissolute, a big liar with different faces, a dishonest person with some false instruments such as drugs for deceiving and making a fool of his followers to improve his unique plan. Bartol draws this picture of him: To women he is unfaithful and regards them as mean creatures and exploits them (Miriam, Apama, the garden girls and his daughters). Not so strict about Islamic guidelines and regulations, he easily changes them in different situations such as drinking wine that sometimes can be permitted. To his family he is indifferent, unfeeling and more than this, cruel. He sends his daughters to work, and the way they talked about their father's feeling towards them is alarming, and also sentenced his son to death. To his friend he is jealous and also hard-hearted: we see the way he behaved to Khaje Nezam in the story as a positive character and a friend who had done everything good for Hasan but was killed by him nonetheless. To people he is oppressive; he sends the best and bravest men towards death mercilessly. To himself also he is cruel, so that at the end he is alone, a madman, just thinking about his evil plan against humanity. As far as God goes, Hasan sees himself as the center of the universe and everything is in his hand if he wants. He considers himself to be God by himself; once he said I am the savior of human beings, and once he said I want to get into God's position. One can imagine that Bartol meant to make this character incomparable even with Satan.

When Bartol's Hasan talks about his beliefs he reminds Miriam about a secret he's benn carrying around for twenty years: "a long-ranged plan that I've transformed from fantasy into reality", and also 
(...) Of all the warriors for the Muslim faith, Ali (first Imam of Shiite) was closest to my heart. Everything about him and his descendants was full of mystery. But the thing I found most moving was the promise that Allah would send someone from his (Ali's) line into the world as the Mahdi, to be the last and greatest of the prophets. (Biggins 2005, 142)

Then he says, “(...) on lonely nights I would even wonder if I weren't the awaited savior myself" (ibid.). We can see even his belief as a Shiite is from a strange sort and not the same as a real believer. It seems that Bartol intends to show that he was an adventurous character that was interested in Shiism because he thinks that it is "mysterious". And at last Bartol's Hasan sees himself to be Mahdi, the Savior. He from his childhood (12 years old) heard about various sects from his teacher Amireh Zarab, including the Ismaili sect and also about disputes between different sects. He says, "I decided that from then on I wouldn't worry about doctrinal disputes but (...) attainable things..." (ibid.)

Bartol's Hasan talking over his doctrine thinks that

but somewhere at the bottom of my heart I still missed those fairy tales from my earliest youth. My tenacious faith in the coming of Mahdi and the great mysterious of the prophet's succession. (...) the evidence was mounting in support of the thesis that nothing is true. (ibid.)

Then he disputes about the followers of different beliefs and religions that all of them claims that they are right and others are wrong. Then he says more and more he began to see the supreme wisdom of the Ismaili dais: "truth is unattainable to us, it doesn't exist for us. If you don't believe in anything, then everything is permitted, then follow your passion". To get these ideas he was impressed profoundly by the doctrines heard from Abu Nedjam Saradj who said the "doctrine of Ali and Mahdi is just bait for the masses of believers... and a fairy tale. Because the truth is unknowable, therefore we believe in nothing and have no limits on what we can do..." (ibid., 143). When Hasan asks about the point of deceiving people, Saradj answered "Don't you see we have become slaves of the Turks?" (ibid.) and then confessed that he uses the name Ali as a sacred name to unite the masses against the rulers. Bartol's Hasan confesses to Miriam that after getting these insights from Abu Seradj, "It was an entirely new person reawakening to life".

In creating Hasan's plan, as the most important plotline, Bartol puts a discussion between Omar Khayyam and Hasan when "at the moment a powerful and immutable plan was born in me" describing it as "the likes of which the world had 
never seen". The plan was "to test human blindness to its utmost limits. To use it to attain absolute power and independence from the whole world." He thinks that now he can embody the fairy tale and turn it into such a reality that "our remotest descendants would talk about it". He talks like a god "to conduct a great experiment on man" (Biggins 2005, 148).Yes, this is what Bartol made elegantly.

\section{Hasan Sabbah, the Ruler of Alamut in the 11th Century}

Now we turn to Hasan Sabbah, the leader of the Ismaili sect in the 11th century. He seems to be not much the same as Bartol's version, in personality and thinking. What made Hasan Sabbah such a unique personality with a weird way of competing against his enemies? Daftary, who is an expert in Ismaili history and studies, describes the reasons of Hasan's hostility with the Seljuks, He thinks that Hasan Sabbah seems to have had a complex set of religio-political motives for his revolt against the Seljuks. As Shii Ismaili, he could not have tolerated the ardently Sunni Seljuk Turks' hostility towards Shi' ism and their aim to uproot the Fatimid caliphate (Daftary 1996, 34-37). He also puts forward Hasan's nationalistic mentality as one of the possible reason for his revolt showing "the Persians' resentment over the alien rule of the Seljuk Turks". Hasan's ethnic identity has given as another reason for his hostility towards Turks and Daftary thinks that Hasan took the unprecedented step of replacing Arabic with Persian as the religious language of the Ismailis of Persia (ibid., 34-37). Regarding the words and concepts of assassins, hashashin and hashish, Daftary $(2007,19-24)$ discusses in details and calls administrating hashish to the fedayeen (his followers), a fictional tale that "neither the Ismaili texts nor any serious contemporary Muslim sources in general attest to the actual use of hashish, with or without gardens of paradise, by the Nizaris...”. (ibid., 24)

Hasan's doctrines have been presented in his treatise entitled Chabar Fasl, meaning Four Chapters (Shahrastani 1968 II, 195-98). In this book he presents a new teaching or preaching ( $a l-d a$ 'wa al-jadida), which Daftary believes is a "reformulation of the established Shii doctrine of ta'lim (authoritative instruction)". He views that the way Hasan restates the doctrine is more vigorous. In his treatise, in the first chapter, Hasan argued for the inadequacy of human reason and wisdom in knowing God and in the second chapter he describes the necessity of an authoritative teacher (mu'allim-i sadiq) as the spiritual guide of men, in the third and fourth chapters the idea of the necessity of having a constant and identified teacher for human beings has been provided and at last he concludes about the people who are different from each other on the notion of the necessity of having a guide 
(Daftary 1990, 340-4, Shahrastani1968, II: 195-8; Juwayni 1992, 48-52; Rashidal-Din 1959, 149-53, 105-7; Kashani 1987, 133-72, 186-90, 142-43). His doctrine of a'lim, emphasizing the autonomous teaching authority of each imam in his own time, became the central doctrine of the Nezaris based on Hasan's ideas (Daftary 1990, 340-4; 361-5). Shahrestani, who is Hasan Sabbah's contemporary and is completely familiar with the Ismaili sect's doctrine, described some of the beliefs of Hasan Sabbah written in Chahar Fasl. He says Hasan Sabbah believed that being rational or wise is not enough to understand the truth, as a result to identify and perceive God (Hagh). If people were left alone in such a situation, they go astray. Then Hasan comes to this conclusion that people need to have a teacher, mu'allim-i sadiq (honest teacher), who is Imam-e- ma'soom (innocent religious leader) from a holy origin and selected by God (Shahrestani 1968, 195-8).

About Hasan's Personality, based on the documents, mainly in the books written by three main mentioned historians in the Ilkhanate courts, Hasan Sabbah's had mystic and simple way of life and his sound behaviors were sample for his followers. It was said that he very strictly followed the Islamic regulations and guidelines and did justice to all people the same. For example he considered drinking wine a great sin, and he could not tolerate this even for his own son. He also believed in earning life through physical working, because of that most of fedayeen (his followers) were farmers. Also after each victory Hasan never condemned nor avenged the defeated people. Daftary writes that based on the mentioned documents, Hasan sent his wife and daughters away permanently to Girdkuh to be safe from the war, and he asked them to earn their living by spinning (1996, 34-37). Ibn-e-Athir (1885, 625), Juwayni (1992, 215), Rashid al-Din Fazlollah $(1959,133)$ and Kashani $(1997,168)$ all described Hasan's unique personality as a philosopher, astrologist, and lecturer who had the strong power of leadership and management in politics and in war affairs as well.

To be more familiar with Hasan Sabbah's personality and beliefs we take a look at some other historical documents. It makes us more aware of the political situation of that period, as we know he ruled over his own realm in the middle of a country as well as preached a doctrine different from the central kingdom called the Seljuks. There are two valid letters remained from Malekshah, the king and Hasan, the ruler of Alamut Castle, corresponded with each other in $484 \mathrm{HJ}$. Malekshak sent the letter to Hasan by Ziaadin Khaghan, his prime Vazir (minister), to threated Hasan for having this "new nation and religion" and mentioned that "you sent some stupid persons to hit people with a knife" and then warns him if he does not put aside this misleading behavior, he will send his men to destroy Alamut (manuscript 2012). The way Hasan answered Malekshah is gentle and exactly different from the rough and rude voice of Malekshah but vigorous. First he 
says that he welcomed the message and the messenger. He reasoned that he has not brought a new religion but it is what the Prophet Mohammad said. Then he tries to describe his situation and Khaje Nezam's hostility, "I do not have any affection for this world and its affairs", but "just I think that Prophet Mohammad's offspring have the right to be his successors as Muslim Khalife (leader and ruler)" and then he wished that the king could identify the truth and God helps them find it. In some part of the letter Hasan says that if the king does not accept his words honestly, he will be forced to do something against the king (Ravandi 1997, 196). These letters may unravel the struggle between Hasan and Malekshah and the way they regard each other and also the real attitude between Hasan and Khaje Nezam towards each other. Rashid al-Din wrote that he mostly spent his life teaching his doctrine, searching and writing books as well as handling the affairs of his realm and it has been said that he came out of his personal chamber just few times during more than his thirty years as the ruler of Alamut $(1959,133-4)$. About his fedaiyeen, Ibn-e-Athir $(1885,66)$ narrated in detail some real stories about brave fighting from some of them. On the other hand some of the historians, such as Juwayni $(1992,72)$, report that if Hasan couldn't capture a place through peace and by invitation, he tried to get it by any means such as murdering, and if the place was suitable to build a castle on it, he surely did it.

\section{Discussion and Conclusion}

We return back to the questions put forward at the beginning of the article. Hasan Sabbah (1050-1124), was a real person, a powerful religious and political leader ruled over a mountain fortress called Alamut Castle in the north part of Iran and he was against the dominant Seljuk Turks. He founded a group of fedayeen as his members. There are quite a lot historically valid documents about all the happenings of his period. But we know that Bartol's Alamut as a literary work drew its inspiration firstly from history, based on Polo's story about Alamut narrated from the local Iranian people. But this is not the only thing he borrowed from history; he also used some deliberate religious insights, beliefs, and knowledge about characters. $\mathrm{He}$ modified them as he intended carefully. As a matter of fact he could make different knowledge including history, philosophy, imagination, and literature to be at his own service for conveying his own nationalistic message to his people. Biggins wrote that Bartol incorporated many of his own qualities and personal interests into portraits of Hasan and the novel's other characters. Also he says he was an "avid student" of philosophy, history, mathematics, and the natural sciences (Biggins 2004, 436).

To mark the occasion of a 1957 edition of Alamut, Bartol talks to the books readers in a solicitous tone. He condemns the "terrible, inhuman, despicable methods" 
used by Hasan, and about the "solidarity" and "friendship" among the fedaiyeen and girls that "never die" (Biggins 2004, 436). He talks about Ibn-e-Taher, who at last searches for "truth". As we get from history, Ibn-e-Tahir was murdered immediately after killing Khaje Nezam, but in the novel, for Bartol, he remains alive as a symbol of the young people of his country. And more important than all, he reveals Bartol's aim and his feeling of writing Alamut. He says: "Friend! Brother! Let me ask you; is there anything that makes a person braver than friendship? Is there anything more touching than love? And is there anything more exalted than the truth?"We can see that this is Bartol's message years after Alamut's publication. His message now is different from the one in the novel. He says that he wrote the novel for "friendship", for "love", and for "truth". He as an older Bartol does not like to encourage the people to behave like Hasan or fedaiyeen because the situation has changed now.

As Biggins considers the Alamut of Bartol as a work of literature with a specific task, not "conveying facts in a linear way", I think also it is not. Biggins expects a literary work can explore universal truths about human life and he thinks that Bartol has done this so carefully that our conception through some "subtle clues" has been led to distinguish between truth and delusion. And Bartol knew this well as a literary artist too. Through such a high caliber work of art he could send his message to his nation: this kind of Hasan Sabbah, as a leader, will be lonely and unhappy at last. But Ibne-Tahir perhaps his symbol for the young people in his nation should seek truth and hate deception. He does not admire Hasan Sabbah in his commentary and asks the people, if they are subjected to his inhumane methods, "never to lose their most noble values". Then at last Bartol demolished his splendid idol deliberately.

Now my last word is that Bartol did not have any concern about anywhere except for his own country and his own nation. He employs some real facts to merge them with his own favorite intentions and desires with an incredible taste of imagination to create the wonderful Alamut. Bartol's novel, in Biggin's words, is a sublime "work of literature", but what made it sublime? Surely the deep wound and profound sorrow for his nation and his home land (from which the older Bartol in 1957 had to some extent recovered) helped this literary work to become sublime, which Hladnik's interpreted as nationalistic feelings.

\section{References}

Biggins, Michael, trans. 2004. Alamut of Vladimir Bartol. Seattle, Washington: Scala House Press.

—. 2005. "Against Ideologies: Afterword." In Alamut by Vladimir Bartol, translated by Michael Beggins, 428-38. Ljubljana: Sanje. 
CVG UK Staff. 2006. “Interview: Assassin's Creed.” November 7. Producer Jade Raymond. CVG. Accessed September 2, 2012. http://www. computerandvideogames.com/148805/ interviews/assassins-creed/.

Daftary, Farhad.1990. The Isma ilis: Their History and Doctrines. Cambridge: Cambridge University Press.

—. 1996. The Encyclopaedia Iranica, Vol. XII. NewYork: Columbia University.

—. 2007. “The Ismaili Historiography.” In Encyclopaedia Iranica, edited by Ehsan Yarshater, 178-95. New York: Columbia University. www.iis.ac.uk/ SiteAssets/pdf/ ismaili_studies.pdf.

Hafiz, Abru Shahab adin. 1985. Majma' al-tawarikh al-sultaniya: qismat-i

khulafa' 'Alawiya-ye Maghrib wa Misr wa Nezariyan, edited by M.

Mudarresi-Zanjani. Tehran: M.Mudarresi-Zanjani Publisher.

Hladnik, Miran. 2005. "Nevertheless, Is It also a Machiavellian Novel?" Slovene Studies Journal 26 (1-2): 107-15.

Ibn, -E-Athir.1885. Al-Ta'rikh al-kamil, IX. Cairo: Maktab al- anjelo al-mesriye. Juwayni', Ata Malik.1992. Ta'rikh-i jahan-gushay. Tehran: Arghavan Publisher. Kashani, Abu'l-Qasim 'Abd Allah b. 'Ali. 1997. Zubdat al-tawarikh: bakhsh-i

Fatimiyan wa Nizariyan, edited by M. T. Daneshpazuh. Tehran: M. T. Daneshpazuh Publisher.

Ravandi, Morteza. 1997. The Social History of Iran. Town: Arash Publisher. Manuscript. 2012. "The Letter of Malekshah to Hasan Sabbah." Content Owner: Library, Musum and Document Center of Iran Parliament. Record established Date: 1391/10/22HJ, Record Date: 1389/11/30HJ

Moulana Jalāl ad-Dīn Muhammad Rūmī, J. 1898. The Masnavi, translated by E.H. Whinfield, Book I. Prologue. http://muslimcanada.org/sufi/ book1rumi.htm.

Mustawfi, Hamd Allah. 1960. Tarikh-i gozida, edited by 'Abd al-Husayn Nava'i. Tehran: Amir Kabir Publisher.

Polo, Marco. 1920. The Travels of Marco Polo. Translated by Henry Yule, edited and annotated by Henri Cordier, Book 1. London: John Murray.

Rashid al-Din, Fazlollah. 1959. Jami' al-tawarikb: qismat-i Isma 'iliyan, edited by And published by M. T. Daneshpazuh and M. Mudarresi-Zanjani. Tehran: M. T. Daneshpazuh and M. Mudarresi-Zanjani Publishers.

Shahrastani, Abu'l-Fath. 1968. Kitab al-milal wa'l-nihal. Cairo: Maktab alanjelo al-mesriye. 